\title{
Antimicrobial activity of Streptomyces spp. isolated from Apis dorsata combs against some phytopathogenic bacteria
}

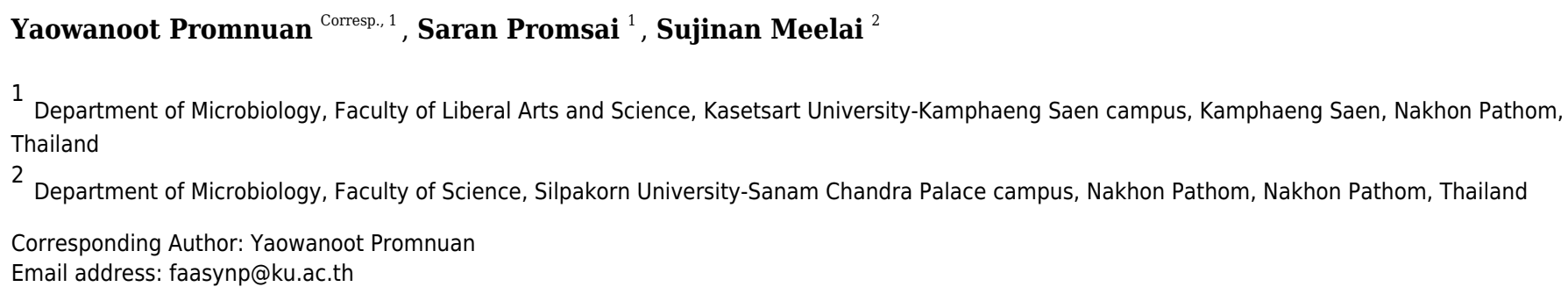

The aim of this study was to investigate the antimicrobial potential of actinomycetes isolated from combs of the giant honey bee, Apis dorsata. In total, 25 isolates were obtained from three different media and were screened for antimicrobial activity against four plant pathogenic bacteria (Ralstonia solanacearum, Xanthomonas campestris pv. campestris, Xanthomonas oryzae pv. oryzae and Pectobacterium carotovorum). Following screening using a cross-streaking method, three isolates showed the potential to inhibit the growth of plant pathogenic bacteria. Based on a 96-well microtiter assay, the crude extract of DSC3-6 had minimum inhibitory concentration (MIC) values against $X$. oryzae $\mathrm{pv}$. oryzae, $X$. campestris pv. campestris, $R$. solanacearum and $P$. carotovorum of $16,32,32$ and $64 \mathrm{mg} \mathrm{L}^{-1}$, respectively. The crude extract of DGA3-20 had MIC values against $X$. oryzae pv. oryzae, $X$. campestris pv. campestris, $R$. solanacearum and $P$. carotovorum of $32,32,32$ and $64 \mathrm{mg} \mathrm{L}^{-1}$, respectively. The crude extract of DGA8-3 at $32 \mathrm{mgL}^{-1}$ inhibited the growth of $X$. oryzae pv. oryzae, $X$. campestris pv. campestris, $R$. solanacearum and $P$. carotovorum. Based on their 16S rRNA gene sequences, all isolates were identified as members of the genus Streptomyces. The analysis of 16S rRNA gene sequence similarity and of the phylogenetic tree based on the maximum likelihood algorithm showed that isolates DSC3-6, DGA3-20 and DGA8-3 were closely related to Streptomyces ramulosus (99.42\%), Streptomyces axinellae (99.70\%) and Streptomyces drozdowiczii (99.71\%), respectively. This was the first report on antibacterial activity against phytopathogenic bacteria from actinomycetes isolated from the giant honey bee. 
1 Antimicrobial activity of Streptomyces spp. isolated from Apis dorsata combs against some

2 phytopathogenic bacteria

3

4 Yaowanoot Promnuan ${ }^{1}$, Saran Promsai $^{1}$, Sujinan Meelai ${ }^{2}$

5

$6{ }^{1}$ Department of Microbiology, Faculty of Liberal Arts and Science, Kasetsart University-

7 Kamphaeng Saen campus, Nakhon Pathom, Thailand

$8{ }^{2}$ Department of Microbiology, Faculty of Science, Silpakorn University-Sanam Chandra Palace

9 campus, Nakhon Pathom, Thailand

10

Corresponding Author:

Yaowanoot Promnuan ${ }^{1}$

Department of Microbiology, Faculty of Liberal Arts and Science, Kasetsart University-

Email address: ypromnuan@gmail.com; faasynp@ku.ac.th

\section{Abstract}

The aim of this study was to investigate the antimicrobial potential of actinomycetes isolated from combs of the giant honey bee, Apis dorsata. In total, 25 isolates were obtained from three different media and were screened for antimicrobial activity against four plant pathogenic bacteria (Ralstonia solanacearum, Xanthomonas campestris pv. campestris, Xanthomonas oryzae pv. oryzae and Pectobacterium carotovorum). Following screening using a crossstreaking method, three isolates showed the potential to inhibit the growth of plant pathogenic bacteria. Based on a 96-well microtiter assay, the crude extract of DSC3-6 had minimum inhibitory concentration (MIC) values against $X$. oryzae pv. oryzae, $X$. campestris pv. campestris, $R$. solanacearum and $P$. carotovorum of 16, 32, 32 and $64 \mathrm{mg} \mathrm{L}^{-1}$, respectively. The crude extract of DGA3-20 had MIC values against $X$. oryzae pv. oryzae, $X$. campestris pv. campestris, $R$. solanacearum and $P$. carotovorum of 32, 32, 32 and $64 \mathrm{mg} \mathrm{L}^{-1}$, respectively. The crude extract of DGA8-3 at $32 \mathrm{mgL}^{-1}$ inhibited the growth of $X$. oryzae pv. oryzae, $X$. campestris pv. campestris, $R$. solanacearum and $P$. carotovorum. Based on their $16 \mathrm{~S}$ rRNA gene sequences, all isolates were identified as members of the genus Streptomyces. The analysis of $16 \mathrm{~S}$ rRNA gene sequence similarity and of the phylogenetic tree based on the maximum likelihood algorithm showed that isolates DSC3-6, DGA3-20 and DGA8-3 were closely related to Streptomyces ramulosus (99.42\%), Streptomyces axinellae $(99.70 \%)$ and Streptomyces drozdowiczii (99.71\%), respectively. This was the first report on antibacterial activity against phytopathogenic bacteria from actinomycetes isolated from the giant honey bee. campestris pv. campestris, Xanthomonas oryzae pv. oryzae, Pectobacterium carotovorum

\section{Introduction}


The Gram-negative bacteria Xanthomonas campestris pv. campestris, Xanthomonas oryzae pv. oryzae, Ralstonia solanacearum and Pectobacterium carotovorum are known to cause significant losses in many crop plants worldwide. X. campestris pv. campestris is a seed-borne pathogen that causes black rot disease in a large number of species of the Brassicaceae, including the genera Brassica and Arabidopsis. The typical disease symptoms include V-shaped yellow lesions starting from the leaf margins and blackening of the veins (Vicente \& Holub, 2013). $X$. oryzae pv. oryzae causes devastating bacterial bright leaf (BLB) disease, which is one of the major diseases of rice in Asian countries. This bacterial pathogen grows in the xylem vessel, causing yellow/white lesions along the leaf veins (Xie et al., 2018). $R$. solanacearum is the causal agent of bacterial wilt, which is one of the most devastating plant diseases worldwide. This soil-borne vascular pathogen can cause disease to many economically important crops, including tomato, potato, eggplant, tobacco and banana. The bacterium infects plants via wounds or root tips; it invades the xylem vessels and systematically spreads to the aerial parts of the plant through the vascular system (Ombiro et al., 2018). P. carotovorum, formerly known as Erwinia carotovora, is one of the most destructive diseases of postharvest vegetables worldwide, especially potatoes, green peppers and Chinese cabbages (Zhao et al., 2013). The bacterium is found on plant surfaces and in soil, where it may enter the plant via wound sites or through natural openings on the plant surface. Once inside the plant, it resides in the vascular tissue and intracellular spaces, where it remains until environmental conditions, including free water, oxygen availability and temperature, become suitable for disease development (Itoh et al., 2003). Soft rot pathogens cause general tissue maceration, termed soft rot disease, through the production of enzymes that degrade plant cell walls.

The management of plant diseases is difficult. The use of resistant cultivars to control bacterial wilt disease is the most economical, environmentally friendly and effective method (Ombiro et al., 2018). The disease control of black rot relies on the use of pathogen-free seed and planting material and the elimination of other potential inoculum sources (Vicente \& Holub, 2013). Currently, the control of postharvest bacterial soft rot depends mainly upon the use of bactericides, such as hypochlorite, formaldehyde solution and antibiotics (Zhao et al., 2013). However, the use of chemical bactericides and antibiotics to control phytopathogenic bacteria could cause serious damage to the environment and human health. Moreover, some emerging strains have shown strong resistance to all these products (Sabir et al., 2017; Mougou \& Boughalleb-M'hamdi 2018; Wu et al., 2019). Therefore, many researchers have focused on the development of alternative methods of controlling plant diseases. The use of antibacterial compounds from plant extracts (Satish et al., 1999; Kaur et al., 2016), validamycin A (Isikawa et al., 2004), xantho-oligosaccharide (Qian et al., 2006) and ralhibitins (Ombiro et al., 2018) to inhibit the growth of phytopathogens has been studied and reported. There have been several studies of antagonistic microorganisms, such as Bacillus spp. and Pseudomonas spp., endophytic actinomycetes and melanogenic actinomycetes to inhibit the growth of bacteria causing black rot and bacterial bright leaf disease (Wulff et al., 2002; Mishra \& Arora, 2011; Zhao et al., 2013; Muangham et al., 2015). Several Streptomyces species, such as Streptomyces aureofaciens, 
81 Streptomyces avermitilis, Streptomyces humidus, Streptomyces hygroscopicus, Streptomyces

82 lividans, Streptomyces lydicus, Streptomyces olivaceoviridis, Streptomyces plicatus,

83 Streptomyces roseoflavus, Streptomyces scabies and Streptomyces violaceusniger, have been

84 used to control soil-borne diseases for their intense antagonistic activities by the production of

85 various antimicrobial substances (Zheng et al., 2019).

86 Actinomycetes, especially Streptomyces species, are well known for producing bioactive

87 compounds which suggests that actinobacteria have the potential to produce antimicrobial

88 compounds against phytobacterial pathogens (Viaene et al., 2016). Actinomycetes isolated from

89 different habitats have been investigated for antimicrobial activities against plant pathogens; for

90 example, melanogenic Streptomyces isolated from rhizospheric soils had the ability to inhibit the

91 growth of rice pathogenic bacteria (X. oryzae pv. oryzae and X. oryzae pv. oryzicola). Among

92 these, isolate TY68-3 had the highest antibacterial activity and siderophore production and had

93 99.6\% 16S rDNA sequence similarity to $S$. indiaensis (Muangham et al., 2014). In addition, $S$.

94 caeruleatus isolated from the rhizosphere soil of Cassia fistula had the highest activity against

95 the soybean pathogen X. campestris pv. glycine (Mingma et al., 2014). Hastuti et al. (2012)

96 reported that endophytic Streptomyces reduced $X$. oryzae pv. oryzae infection in rice. Some

97 isolates were able to improve the growth of rice seedlings, plant height and dry weight. In

98 addition, Streptomyces strain LBR02 had the highest inhibitory activity $(25 \mathrm{~mm}$ diameter

99 inhibition zone) against $X$. oryzae pv. oryzae in vitro. Furthermore, S. violaceusnige (strain A5)

100 was isolated from chitin-rich partially decomposed molted snakeskin and had maximum

101 inhibitory activity $\left(0.625-1.25 \mathrm{mg} \mathrm{mL}^{-1}\right)$ against $X$. axonopodis pv. punicae, the causative agent

102 of oily spot disease in pomegranate (Chavan et al., 2016). These reports indicated that

103 actinomycetes, especially Streptomyces, may provide a new approach for the use of

104 actinomycetes for biocontrol in agriculture.

105 The giant honey bees, consisting of the species Apis dorsata, Apis laboriosa and Apis

106 breviligula, are distributed over a vast geographic area in South and Southeast Asia. In Thailand,

107 only $A$. dorsata is found. Bees of this species build a massive single comb attached under the

108 surface of a stout tree branch or an overhang of a rock face, or sometimes to the eves of buildings

109 or other urban structures (Wongsiri et al. 1996). The actinomycetes associated with $A$. dorsata

110 have never been studied or reported. However, there have been several studies of actinomycetes

111 associated with bees and stingless bees in Thailand. The novel actinomycete species

112 Actinomadura apis was isolated from the honey bee (Apis mellifera) (Promnuan et al., 2011).

113 Two novel species of the genus Streptomyces (Streptomyces chiangmaiensis and Streptomyces

114 lannensis) were isolated from stingless bee (Tetragonilla collina) collected from Chiang Mai

115 Province, northern Thailand (Promnuan et al., 2013). Thirty-two actinobacteria isolates were

116 obtained from honey bees (A. mellifera, Apis cereana and Apis florea). Most of the isolates

117 belonged to the genus Streptomyces. Some less frequent isolates were classified in the genera

118 Nonomuraea, Nocardiopsis and Actinomadura. Moreover, some of these isolates produced

119 antimicrobial compounds that inhibited the growth of the honey bee pathogens Paenibacillus

120 larvae and Melisococcus plutonius, which cause American and European foulbrood diseases in

Peer) reviewing PDF | (2020:04:48395:2:0:NEW 2 Nov 2020) 
121 honey bees, respectively (Promnuan et al., 2009). These studies indicated that actinomycetes

122

123

124

125

126

127

128

129

130

131

132

133

134

135

136

137

138

139

140

141

142

143

144

145

146

147

148

149

150

151

152

153

154

155

156

157

158

159

160

associated with bees have the potential to produce antimicrobial compounds to combat disease in agriculture. However, the rate of discovery of new antibiotics from actinomycetes from common habitats has slowed down; therefore, novel antibiotics must be found from actinomycetes in unexplored habitats (Berdy, 2005).

This study focused on actinomycetes isolated from A. dorsata combs and evaluated their antibacterial activity against plant pathogenic bacteria. According to data obtained in the current study, the antibacterial activity of metabolites from actinomycetes could be implemented against phytopathogenic bacteria to assist in crop protection.

\section{Materials \& Methods}

\section{Sample collection}

Three combs of the giant honey bee (A. dorsata) were collected from the Mae-rim district, Chiang Mai Province, Thailand in April 2014. Adult bees, pollen and honey were collected and kept in sterile tubes and stored at $-20^{\circ} \mathrm{C}$ until the isolation process.

\section{Actinomycete isolation}

Three adult bees were surface-sterilized using a triple surface-sterilization technique and ground aseptically following the method modified from Photita et al. (2004) and Promnuan et al. (2009). Isolation of actinomycetes from pollen and honey was obtained using a standard dilution plate method on starch casein nitrate agar (Küster \& William, 1964), glycerol-asparagine (ISP5) (Pridham \& Lyons, 1961) and Czapek's agar (Waksman, 1950) supplemented with $25 \mu \mathrm{g} \mathrm{mL}{ }^{-1}$ nystatin and nalidixic acid. Plates were incubated at $30^{\circ} \mathrm{C}$ for $7-21$ days and examined periodically. The actinobacterial colonies were isolated, purified and maintained in yeast extractmalt extract agar (ISP2) (Shirling \& Gottlieb, 1966) slants and stored at $4{ }^{\circ} \mathrm{C}$.

\section{Test organisms}

$X$. campestris pv. campestris, $X$. oryzae pv. oryzae, $R$. solanacearum and $P$. carotovorum were obtained from the Department of Agriculture, Ministry of Agriculture and Cooperative, Thailand. The phytobacterial pathogens were activated and maintained in nutrient agar (NA) and ISP2 agar for $24-48$ hours at $30^{\circ} \mathrm{C}$ before use.

\section{Screening of antagonistic actinomycetes}

In total, 25 actinomycete isolates were evaluated for their activity toward four plant pathogenic bacteria: $X$. campestris pv. campestris, $X$. oryzae pv. oryzae, $R$. solanacearum and $P$. carotovorum using a modified cross streak method (Lemos et al., 1985). Each isolate was streaked on the center of ISP2 and a glucose yeast extract (GYE) (Agate \& Bhat, 1963) agar plate and incubated at $30^{\circ} \mathrm{C}$ for 7 days. Each test organism was streaked across the actinomycete line and incubated at $30^{\circ} \mathrm{C}$ for 24 hours. Then, the inhibition zones were observed and measured. The experiment was conducted in triplicate. 
161

162

163

164

165

166

167

168

169

170

171

172

173

174

175

176

177

178

179

180

181

182

183

184

185

186

187

188

189

190

191

192

193

194

195

196

197

198

199

200

\section{Extraction of bioactive compounds}

The actinobacterial isolates that showed potent activity against the growth of the test organisms in the previous method were grown on ISP2 agar plates and incubated at $30{ }^{\circ} \mathrm{C}$ for 14 days. The metabolites were extracted using a modified extraction method as described by Kumar et al., 2012. The culture medium of each isolate was cut into small pieces (approximately $0.5 \times 0.5$ $\mathrm{cm}$ ), extracted with $200 \mathrm{~mL}$ of ethyl acetate, shaken vigorously on a flask shaker at $150 \mathrm{rpm}$ and $30{ }^{\circ} \mathrm{C}$ for 48 hours and then filtered using filter paper (Whatman No.1). The ethyl acetate fractions were concentrated using a rotary vacuum evaporator at $40{ }^{\circ} \mathrm{C}$. The crude extracts were resuspended in $1 \mathrm{~mL}$ of sterile dimethyl sulfoxide (DMSO) and stored at $-20{ }^{\circ} \mathrm{C}$ until testing for antimicrobial activity.

\section{Determination of the minimum inhibitory concentration (MIC) of selected actinomycetes}

The MIC of crude extract was determined according to Wiegand et al. (2008) with some modifications. The concentrations of the test organisms, $X$. campestris pv. campestris, $X$. oryzae pv. oryzae, $R$. solanacearum and $P$. carotovorum, were adjusted to the equivalent of 0.5 McFarland standard. The crude extract was dissolved in sterile DMSO to obtain an initial concentration of 5,120 $\mathrm{mg} \mathrm{L}^{-1}$. Sterile DMSO was used as a negative control. The MIC of each extract was determined using serial two-fold dilutions in ISP2 broth in a 96-well microtiter plate (concentration range from 0.5 to $256 \mathrm{mg} \mathrm{L}^{-1}$ ). The experiment was performed in triplicate. Each microtiter plate was incubated at $30{ }^{\circ} \mathrm{C}$ for 24 hours. After incubation, the suspension from each well was streaked onto separate ISP2 agar plates and incubated at $30{ }^{\circ} \mathrm{C}$ for 24 hours, after which any growth was observed. The minimum concentrations of the extracts that showed no turbidity and had no bacterial growth on the ISP2 agar plate were recorded as the MIC values.

\section{Identification of actinomycetes using 16S rDNA sequencing}

The selected isolates that showed potent activity against the test organisms were grown in $50 \mathrm{~mL}$ of ISP2 broth and incubated in a shaker $\left(120\right.$ revolutions $\left.\min ^{-1}\right)$ at $30{ }^{\circ} \mathrm{C}$ for 7 days. Then, cells were collected via centrifugation $(91,000 \mathrm{~g})$ for 5 minutes and were washed three times using sterile distilled water. Genomic DNA was extracted, and the 16S rRNA gene was amplified using the methods described by Nakajima et al. (1999). The primers used for amplification were 20F (5'-AGTTTGATCCTGGCTC) and 1540R (5'-AAGGAGGTGATCCAGCC). Then, PCR products were purified using an Invitrogen ${ }^{\text {TM }}$ PureLink ${ }^{\text {TM }}$ PCR Purification Kit (Thermo Fisher Scientific, USA) according to the manufacturer's instructions. Purified PCR products were sequenced by the Sanger method at 1st BASE, Singapore. The highest similarity of actinomycetes with the reference species was confirmed using the NCBI BLAST tool (https://blast.ncbi.nlm.nih.gov/Blast.cgi). The sequences of closely related type strains retrieved from the GenBank database were multiple aligned using Clustal_W in BioEdit Sequence Alignment Editor 7.2.5 (Hall TA, 1999). After multiple alignments, a phylogenetic tree was constructed using the maximum likelihood (ML) method in MEGA X version 10.1.8 (Tamura et 
201

202

203

204

205

206

207

208

209

210

211

212

213

214

215

216

217

218

219

220

221

222

223

224

225

226

227

228

229

230

231

232

233

234

235

236

237

238

239

240

al., 2018) based on a comparison of 1,332-1,374 nucleotides present in all the strains used after elimination of gaps and ambiguous nucleotides from the sequences. Streptomyces thermocarboxydus DSM $44293^{\mathrm{T}}$ was used as an outgroup. Confidence values for branches of the phylogenetic tree were determined using bootstrap analyses based on 1,000 resamplings (Felsentein, 1985). The sequence similarity values were calculated from the pairwise alignments obtained using BioEdit 7.2.5 (Hall, 1999).

\section{Results}

\section{Isolation of actinomycetes from $\boldsymbol{A}$. dorsata}

The samples (adult bees, pollen and honey) were collected from three hives of $A$. dorsata.

Twenty-five morphologically different actinobacterial isolates were obtained from three different media, with $60 \%$ from -ISP5 agar followed by starch casein nitrate agar and Czapek's agar. Most of the actinomycetes were isolated from pollen $(84 \%)$, followed by honey $(12 \%)$ and adult bees (4\%) (Table 1).

\section{Antimicrobial activity against plant pathogens}

Based on screening for antimicrobial activity using the cross-streaking method, three actinomycete isolates (DSC3-6, DGA3-20 and DGA8-3) showed potent activity ( $>10 \mathrm{~mm}$ diameter inhibition zones) against the growth of four phytopathogenic bacteria (X. campestris pv. campestris, $X$. oryzae pv. oryzae, $R$. solanacearum and $P$. carotovorum) on ISP2 agar plates (Fig. 1). The crude extracts of the three isolates were subsequently tested for their MIC levels against the growth of phytopathogenic bacteria. Based on the 96-well microtiter assay, the MIC values of the crude extract of the three actinobacterial strains are shown in Table 2. The MIC value of actinobacterial strain DSC3-6 against $X$. oryzae pv. oryzae was $16 \mathrm{mg} \mathrm{L}^{-1}$, and the MIC values of the crude extracts of DGA3-20 and DGA8-3 were both $32 \mathrm{mg} \mathrm{L}^{-1}$. All isolates inhibited the growth of $X$. campestris pv. campestris, $R$. solanacearum and $P$. carotovorum, with MIC values of 32,32 and $64 \mathrm{mg} \mathrm{L}^{-1}$, respectively.

\section{Identification of actinomycetes using $16 \mathrm{~S}$ rDNA}

The three actinobacterial isolates that showed inhibition of all four phytobacterial pathogens were identified using 16S rDNA sequencing. 16S rRNA gene sequences for strains DSC3-6 (LC536753), DGA3-20 (LC536752) and DSC8-3 (LC536754) were analyzed by BLAST using the GenBank database. The results showed that all strains had high similarity to members of the genus Streptomyces. The almost complete 16S rRNA gene sequences for strains DSC3-6, DGA3-20 and DGA8-3 were compared with the corresponding sequences of closely related strains of the genus Streptomyces. The maximum likelihood tree (Fig. 2) revealed that strains DSC3-6, DGA3-20 and DGA8-3 were closely related to $S$. ramulosus, $S$. axinellae and $S$. drozdowiczii, respectively.

The sequence similarity value between each actinomycete isolate and its closely related type strain was aligned and calculated from the pairwise alignment. The results showed that 
241 DSC3-6, DGA3-20 and DGA3-8 were closely related to S. ramulosus $(99.42 \%)$, S. axinellae

242 (99.70\%) and S. drozdowiczii (99.71\%), respectively (Table 2).

243

244 Discussion

245 This study investigated antagonistic activity against phytopathogenic bacteria of actinomycetes

246 isolated from the giant honey bee (A. dorsata). Using ISP5 agar, DGA3-20 and DGA8-3 were

247 obtained from pollen and honey samples. However, isolate DSC3-6, which had the highest

248 activity against $X$. oryzae pv. oryzae, was obtained from pollen using starch casein nitrate agar.

249 This indicated that using different isolation media may increase the opportunity of finding

250 potential actinomycete strains. The three Streptomyces strains capable of inhibiting

251 phytopathogens were obtained from pollen and honey stored in combs. The actinomycetes may

252 be taken into hives by the worker bees collecting food and/or water from environmental sources

253 outside the hives (Promnuan et al., 2009). Streptomyces were isolated from strawberry flowers

254 and pollen cultivated in high-bed greenhouses in Jinju, Republic of Korea. This study showed

255 that honey bees (A. mellifera) can transfer Streptomyces bacteria among flowers and strawberry

256 plants. In addition, these endophytic Streptomyces had the ability to protect both plant and honey

257 bees from phytopathogenic fungi (Botrytis cinerea) and entomopathogens, respectively (Kim et

258 al., 2019).

259 Based on 16S rDNA sequence analysis, all potent isolates belonged to the genus

260 Streptomyces. Actinomycetes, especially Streptomyces are well known for the production of

261 secondary metabolites with antagonistic activity against phytopathogens (Viaene et al., 2016).

262 There have been reports of actinobacteria associated with insects. For example, Streptomyces,

263 Micromonospora and Actinoplanes isolated from nests of the paper wasp Polistes dominulus

264 could inhibit the growth of Pseudomonas aeruginosa, Escherichia coli, Staphylococcus aureus,

265 Serratia marcescens and Bacillus subtilis (Madden et al., 2013). The Streptomyces spp. isolated

266 from solitary wasp mud nests showed activity against various drug-resistant bacterial pathogens.

267 The isolate MN 9(V) showed activity against both E. coli and P. aeruginosa at a concentration of

$26825 \mathrm{mg} \mathrm{mL}^{-1}$ (Kumar et al. 2012). The novel macrocyclic lactam sceliphrolactam was isolated

269 from mud dauber wasps (Chalybion californicum and Sceliphron caementarium) and could act as

270 an antifungal by destabilizing fungal cell membrane functions (Poulsen et al., 2011).

271 Actinomycetes associated with bees (A. mellifera, A. cereana and A. florea) produce

272 antimicrobial compounds that inhibit the growth of bacterial pathogens causing American and

273 European foulbrood diseases in honey bees (Promnuan et al., 2009). Furthermore, Streptomyces

274 spp. isolated from black dwarf honey bee (A. andreniformis), showed high activity in decreasing

275 the egg hatch rate and increasing the infective second-stage juvenile mortality rate of the root-

276 knot nematode (Meloidogyne incognita) in vitro and reduced root gall of chili in vivo (Santisuk

277 et al., 2018). These results indicated that actinomycetes associated with insects can provide novel

278 antimicrobial products for use in agriculture.

279

280 Conclusions 
281 Bacterial bright leaf disease, which is caused by $X$. oryzae pv. oryzae, is one of the major 282 diseases of rice in Asian countries. This study is the first report of the antibacterial activity of 283 actinomycete species isolated from giant honey bee (A. dorsata) combs. In vitro, the crude 284 extract of $S$. ramulosus (DSC3-6) had the highest activity against the growth of $X$. oryzae pv. 285 oryzae. According to the current results, actinomycetes associated with the giant honey bee could 286 be a good source of bioactive compounds for use in agriculture. In further studies, potent 287 actinomycete strains will be investigated as biocontrol agents with plants under greenhouse 288 conditions.

289

290

291

292

293

294

295

296

297

298

299

300

301

302

303

\section{Acknowledgements}

This research was supported by the Department of Microbiology, Faculty of Liberal Arts and Science, Kasetsart University of the year 2019, by the Research Promotion and Technology Transfer Center (RPTTC) of the Faculty of Liberal Arts and Science, Kasetsart University Kamphaeng Sean campus, Thailand and by Grant SRIF-JRG-2562-04 from the Faculty of Science, Silpakorn University, Nakhon Pathom, Thailand.

\section{References}

Agate AD, Bhat JV. 1963. A method for the preferential isolation of actinomycetes from soils. Antonie van Leeuwenhoek, 29:297-304.

Berdy J. 2005. Bioactive Microbial Metabolites. The Journal of Antibiotics 58:1-26.

Chavan NP, Pandey R, Nawani N, Nanda RK, Tandon DD, Khetmalas MB. 2016. Biocontrol

304 potential of actinomycetes against Xanthomonas axonopodis pv. punicae, a causative agent for

305 oily spot disease of pomegranate. Biocontrol science and technology, 26(3): 351-372.

306 Evolution, 39: 783-791. Felsenstein J, 1985. Confidence limits on phylogenies: an approach using the bootstrap.

307 Hall TA, 1999. BioEdit: a user-friendly biological sequence alignment editor and analysis 308 program for Windows 95/98/NT. Nucleic Acids Symposium Series, 41: 95-98.

309 Hastuti RD, Lestari Y, Suwanto A, Saraswati R, 2012. Endophytic Streptomyces spp. as 310 biocontrol agents of rice bacterial leaf blight pathogen (Xanthomonas oryzae pv. oryzae). Hayati, 311 19(4): 155-162.

312 Itoh IK, Bell KS, Holeva MC, Birch PRJ. 2003. Soft rot erwiniae: from genes to genomes.

313 Molecular plant pathology, 4(1): 17-30.

314 Ishikawa R, Suzuki-Nishimito M, Fukuchi A, Matsuura K. 2004. Effective control of cabbage

315 black rot by Validamycin A and its effect on extracellular polysaccharide - production of

316 Xanthomonas campestris pv. campestris. Journal of pesticide science, 29(3), 209-213.

317 Kaur H, Nyochembeng LN, Mentreddy SR, Banerjee P, Cebert E. 2016. Assessment of the 318 antimicrobial activity of Lentinula edodes against Xanthomonas campestris pv. vesicatoria. Crop 319 protection, 89: 284-288. 
320 Kim D, Cho G, Jeon C, Weller DM, Thomashow LS, Paulitz TC and Kwak YS. 2019. A 321 mutualistic interaction between Streptomyces bacteria, strawberry plants and pollinating bees. 322 Nature Communications 10, 4802.

323 Kumar S, Stecher G, Li M, Knyaz C, and Tamura K. 2018. MEGA X: Molecular Evolutionary 324 Genetics Analysis across computing platforms. Molecular Biology and Evolution, 35:1547-1549. 325 Kumar V, Bharti A, Gupta VK, Gusain O and Bisht GS. 2012. Actinomycetes from solitary wasp 326 mud nest and swallow bird mud nest: isolation and screening for their antibacterial activity.

327 World journal of microbiology \& biotechnology, 28: 871-880.

328 Küster E, Williams ST. 1964. Selection of media for isolation of streptomycetes. Nature, 202: 329 928-929.

330 Lemos ML, Toranzo AE, Barja JL. 1985. Antibiotic activity of epiphytic bacteria isolated from 331 intertidal seaweeds. Microbial ecology, 11: 149-163.

332 Mishra S, Arora NK. 2011. Evaluation of rhizospheric Pseudomonas and Bacillus as biocontrol 333 tool for Xanthomonas campestris pv campestris. World journal of microbiology \& 334 biotechnology, DOI 10.1007/s11274-011-0865-5.

335 Madden AA, Grassetti A, Soriano JN, Starks PT. 2013. Actinomycetes with antimicrobial 336 activity isolated from paper wasp (Hymenoptera: Vespidae: Polistinae) Nests. Environmental 337 entomology, 42(4): 703-710.

338 Mingma R, Pathom-aree W, Trakulnaleamsai S, Thamchaipenet A, Duangmal K. 2014. Isolation 339 of rhizospheric and roots endophytic actinomycetes from Leguminosae plant and their activities 340 to inhibit soybean pathogen, Xanthomonas campestris pv. glycine. World journal of 341 microbiology \& biotechnology, 30: 271-280.

342 Mougou I, Boughalleb-M'hamdi N. 2018. Biocontrol of Pseudomonas syringae pv. syringae 343 affecting citrus orchards in Tunisia by using indigenous Bacillus spp. and garlic extract. 344 Egyptian journal of biological pest control, 28: 60.

345 Muangham S, Pathom-aree W, Duangmal K. 2015. Melanogenic actinomycetes from

346 rhizosphere soil-antagonistic activity against Xanthomonas oryzae and plant-growth-promoting 347 traits. Canadian journal of microbiology, 61: 164-170.

348 Nakajima Y, Kitpreechavanich V, Suzuki K, Kudo T. 1999. Microbispora coralline sp. nov., a 349 new species of the genus Microbispora isolated from Thai soil. International journal of 350 systematic bacteriology, 49: 1761-1767.

351 Ombiro GS, Sawai T, Noutoshi Y, Nishina Y, Matsui H, Yamanota M, Toyada K Ichinose Y. 352 2018. Specific growth inhibitors of Ralstonia solanacearum, Xanthomonas oryzae pv. oryzae, X. 353 campestris pv. campestris, and Clavibacter michiganensis subsp. michiganensis. Microbiology 354 research, 215: 29-35.

355 Photita W, Lumyong S, Lumyong P, McKenzie EHC, Hyde KD. 2004. Are some endophytes of 356 Musa acuminate latent pathogens? Fungal Diversity, 16: 131-140.

357 Poulsen M, Oh DC, Clardy J, Currie CR. 2011. Chemical Analyses of wasp-associated 358 Streptomyces bacteria reveal a prolific potential for natural products discovery. PLoS One, 6(2): 359 e16763. DOI 10.1371/journal.pone.0016763. 
360 Pridham TG, Lyons AJ. 1961. Streptomyces albus (Rossi Doria) Waskman et Henrici:

361 Taxonomic study of strains labeled Streptomyces albus. Journal of bacteriology, 81: 431-441.

362 Promnuan Y, Kudo T, Chantawannakul P. 2009. Actinomycetes isolated from beehives in

363 Thailand. World journal of microbiology \& biotechnology, 25: 1685-1689.

364 Promnuan Y, Kudo T, Chantawannakul P. 2011. Actinomadura apis sp. nov., isolated from a

365 honey bee (Apis mellifera) hive, and the reclassification of Actinomadura cremea subsp.

366 rifamycini Gauze et al. 1987 as Actinomadura rifamycini (Gauze et al.1987) sp. nov., comb. nov.

367 International journal of systematic bacteriology, 61: 2271-2277.

368 Promnuan Y, Kudo T, Chantawannakul P. 2013. Streptomyces chiangmaiensis sp. nov. and

369 Streptomyces lannensis sp. nov., isolated from the South-East Asian stingless bee (Tetragonilla

370 collina). International journal of systematic bacteriology, 63: 1896-1901.

371 Qian F, An L, He X, Han Q, Li X. 2006. Antibacterial activity of xantho-oligosaccharide cleaved

372 from xanthan against phytopathogenic Xanthomonas campestris pv. campestris. Process

373 biochemistry, 41: 1582-1588.

374 Sabir A, El-Khalfi B, Errachidi F, Chemsi I, Serrano A, Soukri A. 2017. Evaluation of the

375 potential of some essential oils in biological control against phytopathogenic agent Pseudomonas

376 syringae pv. tomato. Journal of plant pathology \& microbiology, 8(9): 1000420.

377 Santisuk J, Promnuan Y, Khun-In A, Nimnoi P, Ruanpanun P. 2018. Efficiency of actinomycetes

378 isolated from black dwarf honey bee (Apis andreniformis) in controlling root-knot nematode,

379 Meloidogyne incognita causes root knot disease of chili in greenhouse. Journal of Agriculture

380 34(3), 481-490.

381 Satish S, Raveesha KA, Jandrdhana GR. 1999. Antibacterial activity of plant extracts on

382 phytopathogenic Xanthomonas campestris pathovars. Letters in applied microbiology, 28:145-

383 147. DOI 10.1046/j.1365-2672.1999.00479.x.

384 Shirling EB, Gottlieb D. 1966. Methods for characterization of Streptomyces species.

385 International journal of systematic bacteriology, 16: 313-340.

386 Vicente JG, Holub EB. 2013. Xanthomonas campestris pv. campestris (cause of black rot of

387 crucifers) in the genomic era is still a worldwide threat to brassica crops. Molecular plant

388 pathology, 14(1): 2-18.

389 Viaene T, Langendries S, Beirinckx S, Maes M, Goormachtig S. 2016. Streptomyces as a plant's

390 best friend? FEMS microbiology ecology, 92, fiw119. DOI 10.1093/femsec/fiw119.

391 Waksman SA. 1950. The actinomycetes: Their nature, occurrence, activities and importance.

392 Annales cryptogamici et phytopathologici. 9: 1-230.

393 Wiegand I, Hilpert K, Hancock REW. 2008. Agar and broth dilution methods to determine the 394 minimal inhibitory concentration (MIC) of antimicrobial substances. Nature protocols, 3(2): 163-

395175.

396 Wongsiri S, Lekprayoon C, Thapa R, Thirakupt K, Rinderer TE, Sylvester HA, Oldroyd BP,

397 Booncham U. 1996. Comparative biology of Apis andreniformis and Apis florea in Thailand.

398 Bee World, 77(4): 23-35. 
399 Wu J, Pan X, Xu S, Duan Y, Luo J, Zhou Z, Wang J, Zhou M. 2019. The critical role of 400 cytochrome c maturation (CCM) system in the tolerance of Xanthomonas campestris pv. 401 campestris to phenazines. Pesticide biochemistry \& physiology, 156: 63-71. DOI

402 10.1016/j.pestbp.2019.02.003.

403 Wulff EG, Mguni CM, Mortensen CN, Keswani CL, Hockenhull J. 2002. Biological control of 404 black rot (Xanthomonas campestris pv. campestris) of brassicas with an antagonistic strain of 405 Bacillus subtilis in Zimbabwe. European journal of plant pathology, 10: 317-25.

406 Xie S, Zang H, Wu H, Rajer FU, Gao X. 2018. Antibacterial effects of volatiles produced by 407 Bacillus strain D13 against Xanthomonas oryzae pv. oryzae. Molecular plant pathology, 19(1): $408 \quad 49-58$.

409 Zheng X, Wang J, Chen Z, Zhang H, Wang Z, Zhu Y and Liu B. 2019. A Streptomyces sp.

410 strain: Isolation, identification, and potential as a biocontrol agent against soilborne diseases of 411 tomato plants. Biological Control, 136: 104004.

412 Zhao Y, Li P, Huang K, Wang Y, Hu H, Sun Y. 2013. Control of postharvest soft rot caused by 413 Erwinia carotovora of vegetables by a strain of Bacillus amyloliquefaciens and its potential 414 modes of action. World journal of microbiology \& biotechnology, 29: 411-420. 


\section{Figure 1}

Fig. 1 Inhibitory effect of actinomycetes

Fig. 1 Inhibitory effects of actinomycetes against the growth of 1. R. solanacearum; 2. X. campestris pv. campestris; 3 . X. oryzae pv. oryzae and 4. P. carotovorum on ISP2 agar plates: (a) DSC3-6, (b) DGA3-20 and (c) DGA8-3.

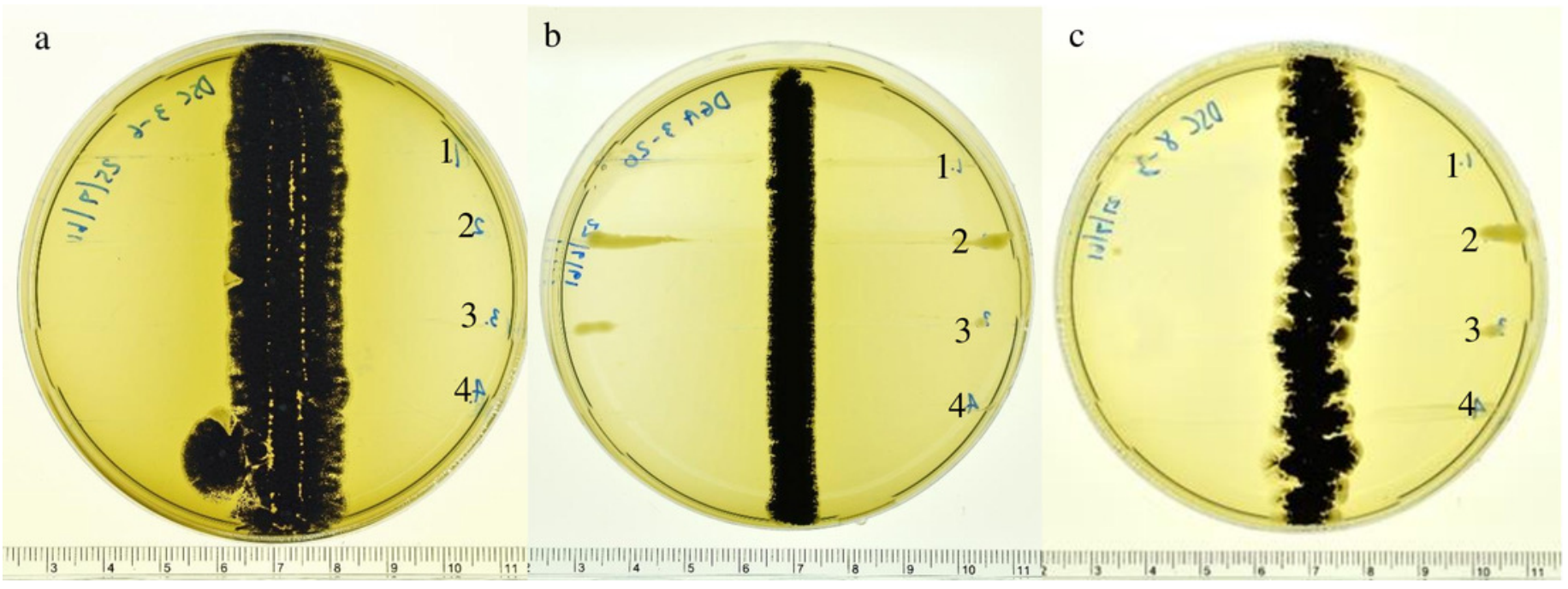




\section{Figure 2}

Fig. 2 Maximum likelihood (ML) tree

Fig. 2 Maximum likelihood (ML) tree based on 16S rRNA gene sequences showing the phylogenetic positions of DSC3-6, DGA3-20 and DSC8-3 relative to type strains of other

Streptomyces species. S. thermocarboxydus DSM $44293^{\top}$ was used as an outgroup. The number at each node is the bootstrap support value (\%) based on 1,000 replicates (only values $>50 \%$ are shown). The scale bar shows 0.010 substitutions per nucleotide position. 


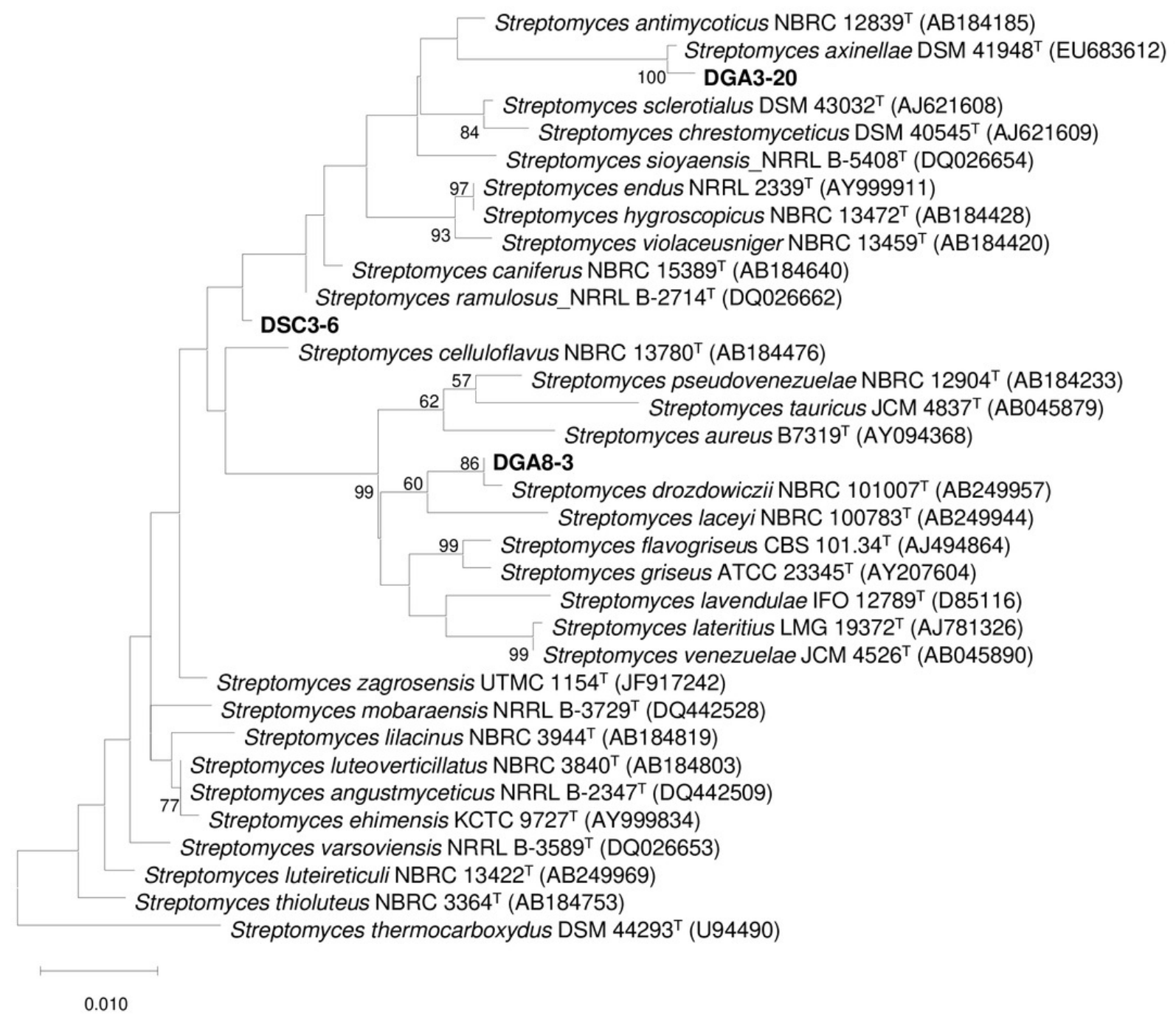




\section{Table $\mathbf{1}$ (on next page)}

Table 1. Numbers of actinomycetes isolated from $A$. dorsata

Table 1. Numbers of actinomycetes isolated from $A$. dorsata using glycerol asparagine agar (ISP5), starch casein nitrate agar (SC) and Czapek's agar (CZ). 
1 Table 1. Numbers of actinomycetes isolated from $A$. dorsata using glycerol asparagine agar (ISP5),

2 starch casein nitrate agar (SC) and Czapek's agar (CZ).

\begin{tabular}{ccccc}
\hline Sample & \multicolumn{3}{c}{ Isolation medium } & \multirow{2}{*}{ Total (\%) } \\
\cline { 2 - 4 } & ISP5 & SC & $\mathbf{C Z}$ & \\
\hline Adults & 1 & 0 & 0 & $\mathbf{1 ( 4 \% )}$ \\
Pollen & 11 & 5 & 5 & $\mathbf{2 1}(\mathbf{8 4 \%})$ \\
Honey & 3 & 0 & 0 & $\mathbf{3 ( 1 2 \% )}$ \\
\hline Total (\%) & $\mathbf{1 5 ( 6 0 \% )}$ & $\mathbf{5 ( 2 0 \% )}$ & $\mathbf{5 ( 2 0 \% )}$ & $\mathbf{2 5 ( 1 0 0 \% )}$ \\
\hline
\end{tabular}

3

4 


\section{Table 2 (on next page)}

Table 2. Characterization and identification of actinomycetes

Table 2. Characterization and identification of actinomycetes using the 16S rDNA gene sequence and minimum inhibitory concentration (MIC) values of actinomycetes against the growth of $1, X$. campestris pv. campestris; $2, X$. oryzae pv. oryzae; $3, R$. solanacearum and 4 , P. carotovorum. 
1 Table 2. Characterization and identification of actinomycetes using the 16S rDNA gene sequence and minimum inhibitory concentration (MIC)

2 values of actinomycetes against the growth of $1, X$. campestris pv. campestris; $2, X$. oryzae pv. oryzae; $3, R$. solanacearum and $4, P$. carotovorum.

\begin{tabular}{|c|c|c|c|c|c|c|c|c|}
\hline \multirow[t]{2}{*}{ Isolate No. } & \multirow[t]{2}{*}{ Morphological characteristic } & \multirow[t]{2}{*}{ Source } & \multirow{2}{*}{$\begin{array}{l}\text { Accession } \\
\text { No. }\end{array}$} & \multicolumn{4}{|c|}{ MIC (mg L $\left.{ }^{-1}\right)$} & \multirow{2}{*}{$\begin{array}{l}\text { 16S rDNA gene } \\
\text { identification } \\
\text { (\% similarity) }\end{array}$} \\
\hline & & & & 1 & 2 & 3 & 4 & \\
\hline DSC3-6 & $\begin{array}{l}\text { Powdery colonies } \\
\text { Substrate mycelium: cream } \\
\text { Aerial spore mass: grey or black } \\
\text { Produce yellow pigment }\end{array}$ & Pollen & LC536753 & 32 & 16 & 32 & 64 & $\begin{array}{l}\text { Steptomyces ramulosus } \\
(99.42 \%)\end{array}$ \\
\hline DGA3-20 & $\begin{array}{l}\text { Powdery colonies } \\
\text { Substrate mycelium: cream or grey } \\
\text { Aerial spore mass: grey or black }\end{array}$ & Pollen & LC536752 & 32 & 32 & 32 & 64 & $\begin{array}{l}\text { Steptomyces axinellae } \\
(99.70 \%)\end{array}$ \\
\hline DGA8-3 & $\begin{array}{l}\text { Powdery colonies } \\
\text { Substrate mycelium: cream } \\
\text { Aerial spore mass: grey or black }\end{array}$ & Honey & LC536754 & 32 & 32 & 32 & 64 & $\begin{array}{l}\text { Steptomyces drozdowiczii } \\
(99.71 \%) .\end{array}$ \\
\hline
\end{tabular}

3 